\title{
The Factory Women
}

\section{Natalie Welsh}

\begin{abstract}
The Factory Women is a fictional account of four Italian immigrant women in Toronto, Ontario in the 1960s. Told from the second person point-of-view, the narrative aims to challenge readers to see the story through the main character's eyes. The women presented in the story sew uniforms in a small workshop that they have dubbed "the factory." One of the women, Marta, lost her husband to the Hoggs Hollow disaster, an actual historical event in which four Italian workers were killed while building a water main tunnel in Toronto. When a mysterious man begins working at "the factory" alongside the women, he tries to encourage them to join a worker's union, much to the disapproval of the workroom supervisor. While Toronto Italians have largely assimilated into mainstream Canadian society, The Factory Women strives to remind members of the ethnic community of their conflicted past in an effort to exhort them to speak out against social injustice now. While many young Italian Canadians have led privileged lives, they must remember the experiences of their own ancestors and continue to fight for the equality of all Canadians. While centred on the Italian experience in Canada, The Factory Women aims to remind all people of the importance of group solidarity.
\end{abstract}

\section{Keywords}

factory, women, country, union 


\section{The Factory Women}

Your son Michele, who usually goes by Mike, tells his cousins that his shortest stint of employment lasted all of two days. The manager would shout at the servers in front of all the customers while they dined on overcooked steaks and mashed potatoes drowned in a vicious brown gravy that dripped off the plates. Mike tells his cousins that his only regret in leaving that joint was that he did not stay long enough to organize the workers. After your son finishes his story, he takes a drag on his cigarette, then throws his head back and laughs.

The first time you picked up a needle, you were just four years old, and by the time you were ten, you were sewing baptismal gowns - as soft and white as angels' wings - for babies in your village and beyond. Some of those sickly babies took their last breaths just days after the priest had poured the sacred water onto their foreheads. It was a good thing those little ones had been baptized, or they would not have made it to Heaven.

When you were just a teenaged bride, you followed your husband to this country. In this country, you both hoped to create your own heaven. You hoped that you would make so much money that you wouldn't have to grow your own food anymore - no, you would buy it from a big store where ladies in pillbox hats pushed metal carts filled with chunks of meat wrapped in cellophane packages. You said nothing when the tomatoes you eventually grew in your new backyard tasted nothing like the ones back home, not wanting to seem ungrateful after your husband had toiled for years just to bring you to this country. When a pillbox hat lady from down the street brought you a wobbling red mass on a floral plate, you said "thank you" in your heavily accented English. You noticed that the lady had brown spots all over her face and up and down her arms. When the freckled pillbox hat lady left, you had no idea what to do with the red mass, so you quietly dropped it into the kitchen garbage bin. The next day, you returned the floral plate. A flaxen-haired man answered the door, said something you couldn't understand, and gestured for you to come inside. Frightened, you ran across the street to your own house, locking the door behind you. You closed all the heavy red and white checkered drapes and prayed to Agnes of Rome, the patron saint of chaste women.

Before Mike was born, you worked at a small factory, spending six hours each day bent over a sewing machine, Monday to Saturday. On Sunday, you went to church. Your husband, who still hates church to this day, stayed home to play cards with his friends from the construction company. At church, you sat beside Enza, your supervisor from the factory who towered over you and all the other women. Whenever Enza spoke in her booming voice, her big arms jiggled like the pillbox hat lady's mysterious red mass.

One Monday morning, a new employee joined the factory: a man with sandy hair sat down behind one of the sewing machines and began working. The only other men at the company worked in the factory office. During the half-hour lunchbreak, Flavia, who had just married an American-born Sicilian, wondered aloud why a man would want to do a woman's job. Rosa, Flavia's older sister, asked why a woman with a rich husband would want to work in the factory, a place the women sometimes referred to as "Hell." Flavia's husband was an accountant and brought home a fat paycheque and a heart-shaped box of candies every Friday evening. Flavia said that she was saving her wages to pay for night school. She was learning English and one day she was going to read the evening news on television. You and the other women just laughed. Who was going to cook her husband's supper if Flavia had to read the evening news on television?

The new man at the factory liked to read both English and Italian newspapers at lunch. He had come from northern Italy, from a province where everyone ate rice. Sometimes, he even ate cold rice for lunch, left over from his supper the night before. He said his wife had died in childbirth in their village and that he had come to this country alone. He started to talk about organizing the workers at the factory. Marta, who had lost her husband at Hoggs Hollow, said that she liked the idea. You said you didn't understand what the man meant by "organizing the workers", so Enza explained, telling you it was a bad idea. You would all be fired if you joined a union. Rosa ran her fingers through her chestnut-coloured hair and laughed - she wouldn't mind getting fired from the factory. Flavia threw a scrap of red fabric at her sister and told her to shut up.

Flavia invited you over for coffee one night after supper. Rosa was there too. Marta had declined Flavia's offer, saying she was just too busy that evening. Flavia's American-born husband sat in the living room, watching Walter 
Cronkite in Southeast Asia. Flavia laughed as she poured the aromatic coffee, joking that maybe Marta had a boyfriend. Rosa told her sister to shut up - that was a terrible thing to say about a widow. Flavia just kept talking: the new man who wanted to organize the workers must be a communist. Weren't all union people communists? That's what Enza had said. Besides, the man was from the north. Weren't communists always from northern parts of countries? Didn't anyone watch the news? There was a war in Vietnam and the communists were from the north. Had everyone already forgotten about Korea?

Marta decided that they couldn't unionize. If Mr. Rossi and the other men in the office fired them all, she, a widow in a new country, would have no other way to take care of her elderly parents and her little boy, the one who had been named after his father - God rest his soul — who had been killed at Hoggs Hollow. Flavia did not want to lose her night school money. Rosa wanted to save money to buy a television set, just like the one that Flavia's husband watched every night. You wanted to save money so that you could resign from your job and stay at home with the baby you were expecting you hadn't told your friends at the factory the good news just yet. That night after supper, you felt too tired to go for coffee at Flavia's. Instead of working on the baptismal gown you had started sewing for the secret growing within you, you went to bed early.

The new man and Marta began sitting together at work, silently sewing the white uniforms that would be worn by hospital workers, and by maids employed in rich people's homes. At lunch, the man started sharing his cold rice with Marta, a village girl from the very south of Italy. Sometimes the man would talk about organizing the workers who wore the uniforms that you and the others sewed in the factory. Enza always told him to pay attention to his work - if they did not meet their quota, they would have to work Sunday and she did not want to miss church. One day, while you and the other women waited for the streetcar that would take you back to your neighbourhood, Flavia warned Marta that if she spent too much time with that man she might become a communist; if she became a communist, this country would send her back to Italy. Marta said the man was not a communist. He just wanted to organize the workers so that they could afford to buy nice things and would never have to work any Sundays. Marta said she wanted to buy nice things: she wanted to buy her son a bicycle. She wanted to buy herself a record player so that she could listen to Nancy Sinatra. As you boarded the streetcar, you heard Flavia tell Marta that she would give her the portable record player she no longer used. When you got off the streetcar in your neighbourhood, you followed the other factory women into the butcher shop where you bought beef cutlets and breadcrumbs to make your husband's favourite supper.

Marta didn't say much after church on Sunday. Flavia invited Marta to her house so that she could give her the portable record player, but Marta said she wanted to go to the cemetery. You stood with the other factory women and watched as Marta left in a different direction than her elderly parents and her little boy. At work that Monday, Marta said that she felt nauseous and tired. During lunch, she sipped some hot tea but refused Flavia's offer of an order of toast from the diner down the street. The new man looked down at the table while he silently ate his chunk of bread and can of pungent sardines. Marta asked to go home early but Enza reminded her that they had a quota. The new man dropped his bread onto the table, stood up, and began shouting in English, telling that old Enza where she could shove her quota. Enza threatened to report him to management but you're still not sure if she ever did.

The next day, the man didn't show up for work. Rosa asked Enza if the factory had finally fired the communist. Enza said she didn't know. Marta surprised you by saying that she hoped she never saw that man or his foul sardines ever again. Then she jumped up from her sewing machine and ran to the bathroom with her hand clamped over her mouth. You and the other women could hear her retching into the toilet. Rosa knocked on the bathroom door and returned to the workroom with Marta, wiping the latter's face with damp toilet paper. Flavia reached into her purse and told you to go and buy Marta a tea from the coffee shop next door. As you left for the coffee shop, you could hear Enza cursing you and the other women through the cigarette that hung from her chapped lips.

The next day, the colour drained from Marta's olive-hued face until her complexion resembled the nurse's cap she was sewing. Marta stood up and shouted when she saw the vermillion pool in the seat of her chair. You and the other women jumped 
up from your sewing machines just as Marta hit the hard workroom floor. Enza's plump limbs shook as she ran toward the office, shouting for someone to call for an ambulance. You felt warm tears fall down your cheeks as the blood continued to seep through the back of Marta's long black and white plaid skirt until it almost resembled a map of Canada. You wiped your face with your trembling fingertips. All Marta wanted from life was to take care of her family and to listen to Nancy Sinatra. Who would take care of her elderly parents and her little boy if something happened to Marta? You watched Rosa and Flavia fuss over Marta while the sisters simultaneously cursed the man from the north.

The factory granted Marta three days to recover from her miscarriage, but she never did return to work. Enza said she was probably fired - why would the factory want to keep a widow who slept with other men and had babies with them? Flavia threatened to sew the old woman's lips shut but Enza just kept talking: she said the factory had already hired a new girl to replace Marta, a girl who had just gotten off the boat and came from a little village so poor and remote that she had never seen a sewing machine and had been too scared to ride the streetcar to her job interview. One Saturday after you had finished work, you went by the house where Marta lived with her parents and little boy. The couple that owned the house told you in your own dialect that Marta and her family had moved away. Had they returned to their village in Italy? The couple wasn't sure.

Years later, you and Flavia were eating lunch in a suburban diner and you swore the waitress looked like Marta, save for the bleached hair and the gaudy makeup layered over her lined face. The waitress wore a name tag that spelled "Marty" and she talked to another customer about Dallas, speculating over who could have shot J.R. Another waitress dropped a coin into the old jukebox and Nancy Sinatra belted out a tune. A few weeks later, Rosa read an obituary in a local Italian-language newspaper about a celebrated union man and swore that the person in the picture looked just like that new man who used to work at the factory. The paper said that the recently deceased man had rallied for workers in the Italian community and beyond. But the man in the paper had a different name so Rosa wasn't so sure it was him. But the obituary said that the union man had spent most of his life a widower and had never had any children.

You handed Mr. Rossi your letter of resignation two weeks before giving birth to Mike. You eventually gave birth to two more children, another boy and a girl. Mike eventually opened his own chain of restaurants alongside his younger brother Anthony, who insisted on giving benefit packages and pension plans to all the employees. You recently moved to the suburbs with your husband and your daughter, Rosemary. Rosemary has grown to be a striking beauty - she has your thick black hair and your husband's bright blue eyes and alabaster skin - but her mind has not grown with the rest of her body. Once a week, you use the public bus to take Rosemary to classes that stimulate her creativity - youth volunteers teach her and other intellectually challenged adults arts and crafts, including how to fashion paper pinwheels and pom-pom animals. You never did return to the factory, instead devoting yourself to your family. You still sew baptismal gowns for acquaintances at church. This past week, you began crafting a baptismal gown for Marta's unnamed baby, lost so many years ago. You tell yourself that you will sell it at a church fundraiser in the hopes that your kindness will ensure that the baby's soul will continue to find serenity in Heaven.

Once a month, you return to the city to attend church with Rosa and Flavia. After Mass, you follow the two sisters to the cemetery, clasping onto Rosemary's slender hand. You, along with Rosa and Flavia, leave fragrant flowers at the grave of Marta's husband, who died at Hoggs Hollow. You never do run into Marta or her kin at the poor man's resting spot. After visiting Marta's husband, you place a bouquet before the small private mausoleum where Enza was interred beside her husband. You take Rosemary's hand in yours and remind her how to make the sign of the cross before Enza's tomb. During the winding bus ride to Flavia's house for lunch, you wonder if Marta really did visit the cemetery after church that Sunday so many years ago.

The workers at the factory never did unionize. After you left, the factory expanded, employing more women and a handful of men. The company opened a second factory in a nearby city. They eventually moved the factories overseas where labour was much cheaper and their workers in this country had to move on to other jobs. Some learned 
a trade or went to study business at community colleges. The older people retired, living off the money that they had saved for decades. Flavia heard that the old factory where you and the other women once worked will be torn down and a new company will come in to build tall towers of luxury condos. Flavia's husband is thinking of buying one now that they are both retired.

You came to this country as a teenaged bride. You now have three grown children, and several grandchildren, all born in this country. Yesterday, a local Italian-language newspaper ran a story on the Hoggs Hollow Disaster. You just turned the page because you have put all the hardships behind you, and you are very grateful for everything this country has given you. Still, you cannot stop thinking of Marta, whose husband died so many years ago. 


\section{Author biography}

Natalie Welsh is an emerging writer and researcher residing in the Greater Toronto Area. She received her BA in Anthropology and her MA in Humanities from York University, Toronto. Prior to embarking on her studies at York, she obtained a TESOL certificate and taught English as a Second Language in Bangkok, Thailand. Natalie has been a lifelong fan of the arts. As a child, she devoured (though not literally!) countless books and her parents' old record collection. A late bloomer in the kitchen, she also enjoys cooking and collecting recipes. Aside from writing, and trying not to overcook family meals, Natalie is passionate about playing and listening to music. After reading the work of authors such as Viet Thanh Nguyen, Nino Ricci, Joy Kogawa, and Nguyen Phan Que Mai, Natalie was inspired to write about her experiences in her own ethnic community. She based The Factory Women on her undergraduate research, old family lore, stories her former co-workers told in the lunchroom, and worlds that exist in her imagination. 